\title{
The African Catfish, Clarias gariepinus, a Model for the Study of Reproductive Endocrinology in Teleosts
}

\author{
P.G.W.J.VAN OORDT* and H.J.TH. GOOS \\ Department of Experimental Zoology, Research Group for Comparative Endocrinology, \\ University of Utrecht, P.O. Box 80.058, 3508 TB Utrecht (The Netherlands)
}

(Accepted 14 December 1986)

\section{ABSTRACT}

Van Oordt, P.G.W.J. and Goos, H.J.Th., 1987. The African catfish, Clarias gariepinus, a model for the study of reproductive endocrinology in teleosts. Aquaculture, 63: 15-26.

In their natural habitat African catfish, Clarias gariepinus, show a discontinuous reproductive cycle. This cycle follows changes in the gonadotropic activity of the pituitary. Gonadotropin release has been shown to be under dual hypothalamic control, i.e. a gonadotropin-releasing hormone (GnRH) and a gonadotropin release-inhibiting factor (GRIF), which turned out to be dopamine.

Gonadal sex hormones influence gonadotropin release by a negative feedback, and a model has been developed to explain their mode of action.

Steroid formation has been studied in testes, seminal vesicles and ovaries and correlated with the annual reproductive cycle. Steroid glucuronides, originating from the seminal vesicle, act as male sex pheromones; ovulation seems to be synchronized by female pheromones.

Techniques for the induction of ovulation were developed. Only broodfish, reared from eggs to maturity under favourable conditions, show a continuous reproductive cycle and can be induced to produce viable eggs throughout the year.

\section{INTRODUCTION}

This paper briefly reviews the publications in this issue of Aquaculture concerning investigations on the reproductive endocrinology of the African catfish, Clarias gariepinus, carried out by the Research Group for Comparative Endocrinology, University of Utrecht, partly in cooperation with the Department of Fish Culture and Inland Fisheries, Agricultural University of Wageningen.

The aim of the studies by this Research Group is to look for causal relationships between the hypothalamo-hypophysial system and the gonads, and to

"To whom correspondence should be addressed. 
investigate the regulation of synthesis and release of hormones produced by these organs as well as the significance of such hormones in the reproductive physiology of the African catfish. Attention is being paid not only to fundamental aspects but also to practical applications concerning the artificial propagation of the African catfish for fish farming purposes.

\section{REPRODUCTIVE CYCLE}

Ecological aspects of the annual reproductive cycle in the African catfish have been studied in detail by Bruton (1979). As a basis for physiological and applied studies, however, histological and biochemical data should be available about cyclical changes in organs involved in reproduction. These include the gonads and the gonadotropic cells of the pituitary. These gonadotropic cells directly stimulate gametogenesis and steroid production in the gonads. Van Den Hurk et al. (1986) carried out a histological and enzyme-histochemical study of the gonads of feral African catfish, and Peute et al. (1986) investigated the ultrastructure of the gonadotropes and the gonadotropin content of the pituitary of these fish (for review: Van Oordt et al., 1987). To that end, male and female African catfish were collected during one year at regular intervals, from a natural population in Northern Israel.

The annual reproductive cycle could be divided into three periods. During the breeding period, from May until August, the pituitary gonadotropin content reaches maximum levels. The gonadotropes are large and densely granulated, even though at least once during that period a gonadotropin surge takes place, leading to oocyte maturation and ovulation, as well as spermiation. Ovulation and spermiation are not fully compensated by the production of new postvitellogenic oocytes and sperm cells respectively, so that during the breeding period gametogenesis comes to an end. Judging from the $3 \beta$-hydroxysteroid dehydrogenase activity, steroid synthesis in the gonads is at its maximum during the breeding period.

In contrast, during the ensuing resting period (September-February) gonadal steroidogenesis is much reduced. Gametogenesis remains absent. The gonadotropes in the pituitary become smaller and show signs of internal hormone breakdown. Accordingly, the gonadotropin content of the pituitary decreases to low values in late autumn.

The third period (March-April) is characterized by a recovery of the gonadotropes, and an increase in pituitary gonadotropin content. This parallels gonadal recrudescence in this period, with full gametogenesis and a restoration of sex steroid synthesis.

Thus, feral African catfish have a discontinuous reproductive cycle, regulated by cyclically active gonadotropes, but this is not the case in African catfish both raised and constantly kept under favourable husbandry conditions. Throughout the year their pituitaries contain large and densely granulated 
gonadotropes (Peute et al., 1984), storing large amounts of gonadotropin (De Leeuw et al., 1985a). The gonads of such animals show a continuous cycle with numerous ripe sperm cells and postvitellogenic oocytes at all seasons (Richter and Van Den Hurk, 1982), but without spontaneous spermiation, oocyte maturation and ovulation (Richter et al., 1987b). The absence of a discontinuity in the annual reproductive cycle under favourable husbandry conditions is primarily the result of the absence of a prespawning gonadotropin surge and a postspawning regression of the gonadotropes.

\section{REGRESSION OF GONADOTROPIN RELEASE}

Because of the central role of gonadotropin in reproductive processes, the regulation of its release from the gonadotropic cells in the pituitary has been the subject of extensive investigations (De Leeuw, 1985; Van Oordt, 1987; De Leeuw et al., 1987). As in mammals, gonadotropin release in teleosts is stimulated by a deca-neuropeptide (for review: Peter, 1983). For the chum salmon (Onchorhynchus keta) and the cod (Gadus morhua morhua) the neurohormone referred to as gonadotropic hormone-releasing hormone ( $\mathrm{GnRH})$ was purified and identified by Sherwood et al., (1983) and by Wu et al. (1986) respectively, and appeared to differ from the mammalian luteinizing hormonereleasing hormone (LHRH) in only two amino acids, i.e. those at the seventh and eighth positions. Several, more or less superactive, analogues of both mammalian LHRH and teleost GnRH have been prepared. Our experiments were carried out with the analogue Des $\mathrm{Gly}^{10}\left[\mathrm{D}-\mathrm{Ala}^{6}\right]$ ethylamine-LHRH (LHRHa), kindly provided by Intervet International B.V., Boxmeer, The Netherlands. Intraperitoneal injections with the peptide $(0.05 \mathrm{mg} / \mathrm{kg}$ body weight) caused the gonadotropin levels in the plasma to increase within 30 min to a maximum at 4-8 h postinjection. Rarely, however, ovulatory levels were reached (De Leeuw et al., 1985a,b, 1987).

Chang et al. (1984) demonstrated that in the goldfish (Carassius auratus) dopamine acts as a gonadotropin release-inhibiting factor (GRIF). Injections with the dopamine antagonist pimozide, a gift from Janssen Pharmaceutica, Beerse, Belgium, in African catfish, however, had no effect at all. On the other hand, in combination with LHRHa, pimozide greatly increased the effect of the releasing hormone analogue, causing plasma gonadotropin to reach ovulation-inducing levels. Thus, it was concluded that dopamine as such has no direct effect on gonadotropin release, but inhibits the GnRH-induced gonadotropin release (De Leeuw et al., 1985a,b, 1987). This was supported by in vivo experiments using dopamine itself in combination with LHRHa (Van Asselt, to be published) and by in vitro experiments in which LHRHa was tested in combination with dopamine and its agonist apomorphine, respectively on pituitary cell suspensions and pituitary fragments (De Leeuw et al., 1986a, 1987). Investigations in progress are dealing with the mode of action of the 
dopaminergic inhibition of $\mathrm{GnRH}$-induced gonadotropin release. Receptor studies are being carried out to investigate the effect of dopamine on $\mathrm{GnRH}$ receptor characteristics. Other experiments include ultrastructural, single cell electrophysiological and biochemical studies to investigate, amongst other things, the effect of $\mathrm{GnRH}$ and dopamine on ion movements along ion channels in the cellular membrane and the interaction of $\mathrm{GnRH}$ and dopamine in influencing the metabolism of second messengers.

In various vertebrates, including teleosts ( see, e.g., Van Putten et al., 1981; Van Oordt and Peute, 1983), castration and steroid replacement experiments have demonstrated a negative feedback of gonadal steroids on gonadotropin release. As for the mode of action of this negative feedback, a model was proposed, based on publications by Ball and Knuppen (1980) and Breuer et al. (1981), stating that steroids can exhibit this effect by interfering with dopamine inactivation (Goos et al., 1985a). De Leeuw et al. (1985c, 1986b, 1987) provided evidence for a possible conversion of aromatizable androgens into catecholestrogens and an interference of the latter with dopamine metabolism within the gonadotropic cells. Moreover, Timmers and Lambert (1987) and Timmers et al. (1987a,b) demonstrated these phenomena in distinct brain centres of the African catfish. Thus, it seems that gonadal steroids can modulate the amount of dopamine available for inhibiting the action of $\mathrm{GnRH}$ when the latter reaches to gonadotropic cells, and at the same time may interfere with dopamine metabolism at the central level, and thus may influence neurosecretory processes regulating gonadotropin release.

\section{SEX PHEROMONES AND REPRODUCTION}

When the annual reproductive cycle largely depends on changes in the gonadotropic activity of the pituitary, and the release of gonadotropin can be influenced by gonadal steroids, it seems that the latter play an important role in regulating reproduction. This role is not necessarily restricted to a purely hormonal function of the gonadal steroids. Presently, there is an increasing interest in the role of sex steroids and their derivatives as pheromones. Two sources have been pointed to with respect to the production of sex pheromones: the gonads and the accessory sex glands (Stacey et al., 1986). As for the more precise chemical nature of the pheromonal steroids, it has been demonstrated that water-soluble steroid glucuronides can act as chemical messengers between conspecifics during the nuptial period (Colombo et al., 1982; Van Den Hurk and Lambert, 1983; Lambert et al., 1986; Van Oordt, 1987; Van Den Hurk et al., 1987b).

It was hypothesized that the absence of spawning in African catfish, kept under husbandry conditions, is caused by a shortage of suitable pheromones, eliciting spawning behaviour, gonadotropin release, oocyte maturation and ovulation. In evaluating this hypothesis, it is necessary to study the production 
of steroids and steroid conjugates in male and female gonads, i.e. the testes and seminal vesicles and the ovaries, respectively, throughout the reproductive cycle, especially shortly before, during and after spawning, and to compare the situation in feral fish with that in fish kept under laboratory and fish farm conditions. Another preliminary question regards the pheromonal function of gonadal excretions.

Much attention has been paid to the question of steroid synthesis. During the breeding season Schoonen and Lambert (1986a,b) and Schoonen et al. $(1987, a, b, c)$ compared the steroid synthesizing capacity of testes and seminal vesicles of spawners, i.e. fish collected during spawning, and non-spawners, i.e. fish not showing breeding behaviour. The spawners were collected in their natural habitat, the Hula Nature Reserve in Northern Israel; the non-spawners came from the same region and from nearby fish ponds. In the testes of nonspawners steroid synthesis was mainly directed towards the production of 11oxygenated androgens and $5 \beta$-pregnane- $3 \alpha, 17 \alpha, 20 \alpha$-triol. In the testes of spawners androgen formation was less pronounced, and the bioconversion of pregnenolone directed more towards the synthesis of progesterone and $17 \alpha$ hydroxyprogesterone. With regard to the seminal vesicles, those of the nonspawners could synthesize the androgens, androstenedione and testosterone, plus pregnenolone ester; and in those of the spawners the production of $5 \beta$ reduced androgens and progestins prevailed. An important difference between the testes and seminal vesicles was the production of steroid glucuronides, which was mainly localized in the seminal vesicles. Both in spawners and non-spawners the seminal vesicles can produce steroid glucuronides with small qualitative and quantitative differences, not reflected by a difference in activity of the enzyme uridine diphospho-glucuronosyltransferase. This indicates that the water-soluble steroid glucuronides may be available during the breeding period, not only in feral catfish, whether they are spawning or not, but also in fish kept in ponds and not spawning spontaneously.

Resink et al. (1987b) compared the capacity to produce highly polar steroids and steroid glucuronides in the testes and seminal vesicles of feral catfish at the end of the resting period, the period of full spermatogenesis and the breeding period. It appeared that the capacity of the testes to convert pregnenolone into $5 \beta$-pregnane- $3 \alpha, 17 \alpha, 20 \alpha$-triol and $5 \beta$-pregnane- $3 \alpha, 17 \alpha$-diol-20-one increases during the period of full spermatogenesis and the breeding period. Moreover, in vitro incubations with androstenedione showed that the capacity of the seminal vesicles to produce testosterone glucuronide increases from the beginning of the period of full spermatogenesis and is followed by an increase in the capacity to produce $5 \beta$-androstane- $3 \alpha, 17 \alpha$-diol glucuronide during the breeding period.

Judging from the presence of the enzymes $3 \beta$-hydroxy steroid dehydrogenase ( $3 \beta$-HSD) and uridine diphosphoglucose dehydrogenase (UDPGD), Van Den Hurk et al. (1987a) concluded that steroid glucuronides can be produced 
by interstitial cells in the testes of feral and laboratory kept catfish and by interstitial cells in the seminal vesicles of feral animals. The presence of UDPGD in the epithelial lining of the seminal vesicle tubules makes it impossible to deny the capacity of steroid glucuronidation to these epithelial cells. A quantitative determination of the two enzymes plus $3 \alpha$-HSD in prespawning and spawning feral catfish, carried out by Resink et al. (1987c), shows an increase in the activity of all three enzymes in the interstitial cells of the seminal vesicles accompanying spawning behaviour. No change was observed in the UDPGD activity of the epithelial cells. In the testes of spawning animals the $3 \beta$-HSD activity had not changed and the UDPGD activity had decreased. Thus, it seems that when it comes to spawning, steroidogenesis increases both in the testes and in the seminal vesicle, and that the production of steroid glucuronides becomes more pronounced in the seminal vesicles. These quantitative enzyme-histochemical data on changes connected with spawning in the synthesis of steroids and steroid glucuronides supplement the above-mentioned biochemical data by Schoonen and Lambert (1986a,b) and Schoonen et al. (1987a,b,c). Resink et al. (1987c) provided evidence that these changes in steroidogenic activity of the testes and seminal vesicles go hand in hand with a rise in plasma gonadotropin level. This indicates a possible influence of gonadotropic hormone on changes in the production of gonadal steroids and steroid glucuronides during spawning in male African catfish.

In feral female African catfish spawning is also accompanied by a rise in plasma gonadotropin level (Resink et al., 1987c). Comparing the capacity of ovarian tissue to metabolize pregnenolone and androstenedione under in vitro conditions, Schoonen et al. (1987d) found that during the breeding period both before and immediately after spawning, the ovaries can synthesize estradiol$17 \beta$, estrone and several progestins and androgens, including $5 \beta$-reduced $\mathrm{C}_{21}$ and $\mathrm{C}_{19}$-steroids. Testerone and most of the $5 \beta$-reduced products were also identified in a conjugated form as steroid glucuronides. In the prespawning ovaries the production of androgens, mainly testosterone, prevailed. Shortly after spawning the synthesis of $5 \beta$-pregnane- $3 \alpha, 17 \alpha, 20 \beta$-triol and of most steroid glucuronides, especially testosterone glucuronide and $5 \beta$-androstane$3 \alpha, 17 \beta$-diol glucuronide, had increased. These products are water soluble, and upon excretion might act as sex pheromones.

Investigations into the possible pheromonal functions of gonadal excretions are being carried out by Resink and colleagues. Attention has been given to attraction of females by males (Resink et al., 1987a). It was observed that female African catfish do not show any interest in males before ovulation, but following induced ovulation can smell and are attracted by substances produced by the seminal vesicles of male conspecifics. Indeed, after ovulation induction, females are attracted by males, but anosmic ovulated females do no react to their presence. Castrated males, with compensatory hypertrophy of the seminal vesicles, are more attractive for ovulated females, whereas males 
with testes but without seminal vesicles are not attractive at all. Recent results (Resink, in preparation) have shown that ovulated females are attracted both by seminal vesicle fluid and by its steroid glucuronide fraction. In addition, preliminary results seem to point to ovulation synchronization in the African catfish, a process in which ovarian fluid produced upon oocyte maturation and ovulation may play an important role (Resink et al., in preparation). Likewise, in the presence of an ovulated female, other female and male catfish appeared to show a rise in the plasma gonadotropin level (Resink et al., 1987a). Thus, it seems that, via the olfactory organ, male and female gonadal pheromones may influence brain centres involved in the regulation of reproduction. Because of that, Resink and colleagues have recently started histochemical studies to follow the nervous pathways connecting the olfactory epithelium with those brain centres. They have also started electrophysiological studies to investigate the sensitivity of the olfactory epithelium to fluid from the seminal vesicle and the ovaries as well as to several fractions of these fluids including steroid glucuronides. At the same time, Schoonen and colleagues are analysing the steroid and steroid glucuronide content of the seminal vesicle fluid.

\section{PRACTICAL APPLICATIONS}

Identification of steroids and steroid glucuronides of gonadal origin and analysis of their pheromonal function may help to overcome the problem of the absence of spontaneous reproduction in African catfish kept under husbandry conditions. In the mean time, endocrinological methods can be used to evoke oocyte maturation and ovulation. As mentioned above, the continuity of the reproductive cycle in African catfish under husbandry conditions is primarily caused by the absence of a prespawning gonadotropin surge. This failure to release a large amount of gonadotropin is not caused by insufficient storage of the hormone in the gonadotropic cells (De Leeuw et al., 1985a), nor to a lack of the gonadotropin release-inducing peptide in GnRH neurones (Goos et al., 1985b). It is more likely that GnRH is not released or is prevented from eliciting its effect. At any rate, a combination of LHRHa and pimozide induces a sharp rise in gonadotropin release and because of that leads to oocyte maturation and ovulation (De Leeuw et al., 1985a,b).

This simple method for obtaining viable eggs, however, meets with both scientific and practical problems. In the first place the role of pimozide is not certain. It might have served as a dopamine antagonist, but might also have inhibited the action of serotonin. In the second place, pimozide cannot be used in fish farming, because it is not commercially available for this purpose. With that in mind, Goos et al. (1987) have tested a number of potentially psychotropic drugs with variable anti-dopaminergic properties and some drugs with specific anti-serotonergic properties, in combination with LHRHa for their gonadotropin release-inducing capacity. The anti-serotonergic drugs had no 
effect at all, but two of the anti-dopaminergic drugs appeared to be very potent, and together with LHRHa caused ovulation in all experimental animals. This means that the absence of a preovulatory gonadotropin surge in captive African catfish has something to do with a dopaminergic inhibition of the action of the hormone that normally induces such a gonadotropin surge. The necessity of combining an anti-dopaminergic drug with a potent LHRH analogue for inducing a strong gonadotropin release, however, indicates that in captive catfish the secretion of $\mathrm{GnRH}$ is inhibited by some factor different from dopamine.

Oocyte maturation and ovulation can also be induced by administering exogenous gonadotropin (Eding et al., 1982). Under field conditions injection of a crude homogenate of catfish pituitaries forms a simple and reliable method (Viveen et al., 1985). Pituitary gonadotropin is believed to induce oocyte maturation and ovulation indirectly by stimulating the synthesis of maturational steroids in ovarian follicles (Goetz, 1983). In general, $17 \alpha$-hydroxy, $20 \beta$ dihydroprogesterone is considered to be the main maturation-inducing steroid in teleosts (Goetz, 1983). In this respect, it is of interest that Richter et al. (1985) succeeded in inducing oocyte maturation and ovulation in the African catfish by administering a precursor of the hormone, i.e. $17 \alpha$-hydroxyprogesterone. Recently, Richter et al. (1987a) compared the effect of pimozideLHRHa and $17 \alpha$-hydroxyprogesterone on oocyte maturation and ovulation, and on the synthesis of various ovarian hormones, including $17 \alpha$-hydroxy,20 $\beta$ dihydroprogesterone. It was found that both treatments are equally successful in inducing oocyte maturation and ovulation. Moreover, gonadotropin appeared to stimulate the production of $17 \alpha$-hydroxyprogesterone rather than the conversion of this hormone to $17 \alpha$-hydroxy, $20 \beta$-dihydroprogesterone.

It is obvious that ovulation induction is of no avail when the ovaries do not contain numerous postvitellogenic oocytes. This means that under natural conditions artificial propagation of African catfish can only be applied successfully during the breeding period and the beginning of the resting period. Bringing mature African catfish from their natural habitat to an indoor hatchery under conditions of optimal food supply, constant water temperature of about $25^{\circ} \mathrm{C}$ and normal local changes in daylength, makes the period of successful artificial propagation increase to 10 or 11 months per year (Richter et al., 1987b). Fish reared from egg to maturity in laboratory tanks under similar feeding and temperature conditions and different photoperiodic regimes showed an uninterrupted ovarian activity with postvitellogenic oocytes at all seasons. All year round such fish could be induced to produce large quantities of viable eggs.

It therefore seems that an endogenous rhythm leading to an inherent discontinous reproductive cycle is normally determined in early life, and can be overcome by proper feeding and by keeping catfish larvae and fingerlings at a constant high temperature. When reaching maturity under such favourable 
conditions, female African catfish will show an constant production and storage of gonadotropin and a continuous limited release of this pituitary hormone. The low concentration of the hormone in the blood is sufficient for the production and maintenance of postvitellogenic oocytes, but not enough for spontaneous oocyte maturation and ovulation. Such animals can, however, be used for artificial propagation at all seasons, and ensure the production of healthy larvae throughout the year. This makes the African catfish a promising species for fish farming in its own area of distribution, i.e. Africa and the Near East, as well as in any other place where favourable conditions can be provided at relatively low costs.

Future results of research dealing with the regulation of gonadotropin release and the role of sex pheromones may help to facilitate a spontaneous gonadotropin surge in captive catfish, and may at any rate assist in improving culture methods. Last but not least, such investigations will contribute to understanding reproductive endocrinology in teleosts.

\section{REFERENCES}

Ball, P. and Knuppen, R., 1980. Catecholoestrogens (2- and 4-hydroxy-oestrogens) chemistry, biogenesis, metabolism, occurrence and physiological significance. Acta Endocrinol. (Copenh.), 93, suppl. 232: 1-128.

Breuer, H., Schneider, H.T., Doberauer, C., Grüber, S. and Ladosky, E., 1981. Effect of oestradiol$17 \beta$ and 2-hydroxy-oestradiol-17 $\beta$ on LH concentration in plasma and COMT activity in hypothalamic nuclei of rats. Exp. Brain Res., suppl. 3: 118-129.

Bruton, M.N., 1979. The breeding biology and early development of Clarias gariepinus (Pisces: Clariidae) in Lake Sibaya, South Africa, with a review of breeding in species of the subgenus Clarias (Clarias). Trans. Zool. Soc. Lond., 35: 1-45.

Chang, J.P., Peter, R.E., Nahorniak, C.S. and Sokolowska, M., 1984. Effects of the catecholaminergic agonists and antagonists on serum gonadotropin concentrations and ovulation in goldfish: evidence for specificity of dopamine inhibition of gonadotropin secretion. Gen. Comp. Endocrinol., 55: 351-360.

Colombo, L., Colombo Belvédère, P., Marconato, A. and Bentivegna, F., 1982. Pheromones in teleost fish. In: C.J.J. Richter and H.J.Th. Goos (Editors), Proc. Int. Symp. Reprod. Physiol. Fish, Wageningen, The Netherlands, 2-6 August 1982. PUDOC, Wageningen, pp. 84-94.

De Leeuw, R., 1985. Regulation of gonadotropin secretion in the African catfish, Clarias gariepinus. Thesis, Univ. Utrecht, The Netherlands, $192 \mathrm{pp}$.

De Leeuw, R., Resink, J.W., Rooyakkers, E.J.M. and Goos, H.J.Th., 1985a. Pimozide modulates the luteinizing hormone-releasing hormone effect on gonadotropin release in the African catfish, Clarias lazera. Gen. Comp. Endocrinol., 58: 120-127.

De Leeuw, R., Goos, H.J.Th., Richter, C.J.J. and Eding, E.H., 1985b. Pimozide-LHRHa-induced breeding of the African catfish, Clarias gariepinus (Burchell). Aquaculture, 44: 295-302.

De Leeuw, R., Smit-Van Dijk, W., Zigterman, J.W.J., Van der Loo, J.C.M., Lambert, J.G.D. and Goos, H.J.Th., 1985c. Aromatase, estrogen 2-hydroxylase, and catechol-O-methyltransferase activity in isolated, cultured gonadotropic cells of mature African catfish, Clarias gariepinus (Burchell). Gen. Comp. Endocrinol., 60: 171-177.

De Leeuw, R., Goos., H.J.Th. and Van Oordt, P.G.W.J., 1986a. The dopaminergic inhibition of 
the gonadotropin-releasing hormone-induced gonadotropin release: an in vitro study with fragments and cell suspensions from pituitaries of the African catfish, Clarias gariepinus (Burchell). Gen. Comp. Endocrionol., 63: 171-177.

De Leeuw, R., Wurth, Y.A., Zandbergen, M.A., Peute, J. and Goos, H.J.Th., 1986b. The effect of aromatizable androgens, non-aromatizable androgens, and estrogens on gonadotropin release in castrated African catfish, Clarias gariepinus (Burchell): a physiological and ultrastructural study. Cell Tissue Res., 243: 587-594.

De Leeuw, R., Goos., H.J.Th. and Van Oordt, P.G.W.J., 1987. The regulation of gonadotropin release by neurohormones and gonadal steroids in the African catfish, Clarias gariepinus. Aquaculture, 63: 43-58.

Eding, E.M., Janssen, J.A.L., Kleine Staarman, G.H.J. and Richter, C.J.J., 1982. Effects of human chorionic gonadotropin (HCG) on maturation and ovulation of oocytes in the ovary of the African catfish, Clarias lazera. In: C.J.J. Richter and H.J.Th. Goos (Editors), Proc. Int. Symp. Reprod. Physiol. Fish, Wageningen, The Netherlands, 2-6 August 1982, PUDOC, Wageningen, p. 195.

Goetz, F.W., 1983. Hormonal control of oocyte final maturation and ovulation in fish. In: W.S. Hoar, D.J. Randall and E.M. Donaldson (Editors), Fish Physiology. Vol. IXB, Reproduction. Academic Press, New York, NY and London, pp. 117-170.

Goos, H.J.Th., Van Der Loo, J.C.M., Smit-Van Dijk, W. and De Leeuw, R., 1985a. Steroid aromatase, 2-hydroxylase and COMT activity in gonadotropic cells of the African catfish, Clarias gariepinus. Cell Biol. Int. Rep., 9: 529.

Goos, H.J.Th., De Leeuw, R., De Zoeten-Kamp, C., Peute, J. and Blähser, S., 1985b. Gonadotropin-releasing hormone-immunoreactive neuronal structures in the brain and pituitary of the African catfish, Clarias gariepinus (Burchell). Cell Tissue Res., 241: 593-596.

Goos, H.J.Th., Joy, K.P., De Leeuw, R., Van Oordt, P.G.W.J., Van Delft, A.M.L. and Gielen, J.Th., 1987. The effect of luteinizing hormone-releasing hormone analogue (LHRHa) in combination with different drugs with anti-dopamine and anti-serotonin properties on gonadotropin release and ovulation in the African catfish, Clarias gariepinus. Aquaculture, 63: 143-156.

Lambert, J.G.D., Van Den Hurk, R., Schoonen, W.G.E.J., Resink, J.W. and Van Oordt, P.G.W.J., 1986. Gonadal steroidogenesis and the possible role of steroid glucuronides as sex pheromones in two species of teleosts. Fish Physiol. Biochem., 2: 101-107.

Peter, R.E., 1983. The brain and neurohormones in teleost reproduction. In: W.S. Hoar, D.J. Randall and E.M. Donaldson (Editors), Fish Physiology. Vol. IXA, Reproduction. Academic Press, New York, NY and London, pp. 97-135.

Peute, J., De Leeuw, R., Goos, H.J.Th. and Van Oordt, P.G.W.J., 1984. Ultrastructure and immunolabelling of gonadotrops and thyrotrops in the pituitary of the African catfish, Clarias lazera. Cell Tisuue Res., 238: 95-103.

Peute, J., Zandbergen, M.A., Goos, H.J.Th., De Leeuw, R., Pinkas, R., Viveen, W.J.A.R. and Van Oordt, P.G.W.J., 1986. Pituitary gonadotropin content and ultrastructure of the gonadotrops in the African catfish, Clarias gariepinus, during the annual reproductive cycle in a natural habitat. Can. J. Zool., 64: 1718-1726.

Resink, J.W., Van Den Hurk, R., Groeninx-Van Zoelen, R.F.O. and Huisman, E.A., 1987a. The seminal vesicle as source of sex attracting substances in the African catfish, Clarias gariepinus. Aquaculture, 63: 115-127.

Resink, J.W., Schoonen, W.G.E.J., Van Den Hurk, R., Viveen, W.J.A.R. and Lambert, J.G.D., $1987 \mathrm{~b}$. Seasonal changes in steroid metabolism in the male reproductive organ system of the African catfish, Clarias gariepinus. Aquaculture, 63: 59-76.

Resink, J.W., Van Den Hurk, R., Voorthuis, P.K., Terlou, M., De Leeuw, R. and Viveen, W.J.A.R., 1987c. Quantitative enzyme histochemistry of steroid and glucuronide synthesis in testes and seminal vesicle, and its correlation to plasma gonadotropin level in Clarias gariepinus. Aquaculture, 63: 97-114. 
Richter, C.J.J. and Van Den Hurk, R., 1982. Effect of 11-desoxycorticosterone acetate and carp pituitary suspension on follicle maturation in the ovaries of the African catfish, Clarias lazera. (C \& V). Aquaculture, 29: 53-66.

Richter, C.J.J., Eding, E.H. and Bloem, A.J., 1985. 17 $\alpha$-Hydroxyprogesterone-induced breeding of the African catfish, Clarias gariepinus (Burchell), without priming with gonadotropin. Aquaculture, 44: 285-293.

Richter, C.J.J., Eding, E.H., Goos, H.J.Th., De Leeuw, R., Scott, A.P. and Van Oordt, P.G.W.J., 1987a. The effect of pimozide-LHRHa and $17 \alpha$-hydroxyprogesterone on plasma steroid levels and ovulation in the African catfish, Clarias gariepinus. Aquaculture, 63: 157-168.

Richter, C.J.J., Viveen, W.J.A.R., Eding, E.H., Sukkel, M., Rothuis, A.J., Van Hoof, M.F.P.M., Van Den Berg, F.G.J. and Van Oordt, P.G.W.J., 1987b. The significance of photoperiodicity, water temperature and inherent endogenous rhythm for the production of viable eggs by the African catfish, Clarias gariepinus, kept in subtropical ponds in Israel and under Israeli and Dutch hatchery conditions. Aquaculture, 63: 169 185.

Schoonen, W.G.E.J. and Lambert, J.G.D., 1986a. Steroid metabolism in the testes of the African catfish, Clarias gariepinus (Burchell), during the spawning season, under natural conditions and kept in ponds. Gen. Comp. Endocrinol., 61: 40-52.

Schoonen, W.G.E.J. and Lambert, J.G.D., 1986b. Steroid metabolism in the seminal vesicles of the African catfish, Clarias gariepinus (Burchell), during the spawning season, under natural conditions, and kept in ponds. Gen. Comp. Endocrinol., 61: 355-367.

Schoonen, W.G.E.J., Granneman, J.C.M., Lambert, J.G.D. and Van Oordt, P.G.W.J., 1987a. Steroidogenesis in the testes and seminal vesicles of spawning and non-spawning African catfish, Clarias gariepinus. Aquaculture, 63: 77-88.

Schoonen, W.G.E.J., Granneman, J.C.M., Lambert, J.G.D., Viveen, W.J.A.R. and Van Oordt, P.G.W.J., 1987b. Quantitative studies of steroid bioconversion in the seminal vesicles of spawning male African catfish, Clarias gariepinus (Burchell), under natural conditions and non-spawning catfish under natural and fish farm conditions. Comp. Biochem. Physiol., in press.

Schoonen, W.G.E.J., Lambert, J.G.D., Resink, J.W., Viveen, W.J.A.R. and Van Oordt, P.G.W.J., 1987c. A quantitative study of steroid conversion in the testes of African catfish, Clarias gariepinus (Burchell), under natural spawning and natural and culture non-spawning conditions. J. Endocrinol., 112: 323-332.

Schoonen, W.G.E.J., Van Bennekom, A.M., Lambert, J.G.D., Viveen, W.J.A.R. and Van Oordt, P.G.W.J., 1987d. Steroidogenesis in pre- and post-spawned ovaries of the African catfish, Clarias gariepinus. Aquaculture, 63: 129-142.

Sherwood, N., Eiden, L., Brownstein, M., Spiess, J., Rivier, J. and Vale, W., 1983. Characterization of a teleost gonadotropin-releasing hormone. Proc. Natl. Acad. Sci. U.S.A., 80: 2794-2798.

Stacey, N.E., Kyle, A.L. and Liley, N.R., 1986. Fish reproductive pheromones. In: D. Duvall, D. Muller-Schwarze and R.M. Silverstein (Editors), Chemical Signals in Vertebrates, Vol IV. Fourth Int. Conf. Chem. Signals in Vertebrates, Lamarie, WY, 27-30 July 1985. Plenum Press, New York, in press.

Timmers, R.J.M. and Lambert, J.G.D., 1987. Measurement of aromatase activity in the brain of the African catfish, Clarias gariepinus. A comparison of two assay methods. Comp. Biochem. Physiol., in press.

Timmers, R.J.M., Lambert, J.G.D., Peute, J., Vullings, H.G.B. and Van Oordt, P.G.W.J., 1987a. Localization of aromatase in the brain of the African catfish, Clarias gariepinus (Burchell), by microdissection and biochemical identification. J. Neurol., in press.

Timmers, R.J.M., Witkamp, R.F., Lambert, J.G.D. and Van Oordt, P.G.W.J., 1987b. The influence of catecholestrone on the metabolism of dopamine, mediated by COMT, in the brain of the African catfish (Clarias gariepinus). Gen. Comp. Endocrinol., in press. 
Van Den Hurk, R. and Lambert, J.G.D., 1983. Ovarian steroid glucuronides function as sex pheromones for male zebrafish, Brachydanio rerio. Can. J. Zool., 61: 2381-2387.

Van Den Hurk, R., Viveen, W.J.A.R., Pinkas, R. and Van Oordt, P.G.W.J., 1986. The natural gonadal cycle in the African catfish, Clarias gariepinus: a basis for applied studies on its reproduction in fish farms. Isr. J. Zool., in press.

Van Den Hurk, R., Resink, J.W. and Voorthuis, P.K., 1987a. An enzyme histochemical study concerning the localization of steroid glucuronide production in the reproductive organs of the African catfish, Clarias gariepinus. Aquaculture, 63: 89-96.

Van Den Hurk, R., Van Zoelen, G.A., Schoonen, W.G.E.J., Resink, J.W., Lambert, J.G.D. and Van Oordt, P.G.W.J., 1987b. Do testicular steroid glucuronides of zebrafish, Brachydanio rerio, evoke ovulation in female conspecifics? Gen. Comp. Endocrinol., in press.

Van Oordt, P.G.W.J., 1987. Modern trends in reproductive endocrinology of teleosts. In: Proc. Vth Congr. Eur. Ichthyol., Stockholm, 12-16 August 1985, in press.

Van Oordt, P.G.W.J. and Peute, J., 1983. The cellular origin of pituitary gonadotropins in teleosts. In: W.S. Hoar, D.J. Randall and E.M. Donaldson (Editors), Fish Physiology. Vol. IXA, Reproduction. Acadamic Press, New York, NY and London, pp. 137-186.

Van Oordt, P.G.W.J., Peute, J., Van Den Hurk, R. and Viveen, W.J.A.R., 1987. Annual correlative changes in gonads and pituitary gonadotropes of feral African catfish, Clarias gariepinus. Aquaculture, 63: 27-41.

Van Putten, L.J.A., Peute, J., Van Oordt, P.G.W.J., Goos, H.J.Th. and Breton, B., 1981. Glycoprotein gonadotropin in the plasma and its cellular origin in the adenhypophysis of shamoperated and ovariectomized rainbow trout, Salmo gairdneri. Cell Tissue Res., 218: 439-448.

Viveen, W.J.A.R., Richter, C.J.J., Van Oordt, P.G.W.J., Janssen, J.A.L. and Huisman, E.A., 1985. Practical manual for the culture of the African catfish (Clarias gariepinus). The Netherlands Ministry for Development Cooperation, Section for Research and Technology, P.O. Box 20061, 2500 EB The Hague, The Netherlands, $128 \mathrm{pp}$.

Wu, P., Ackland, J.F., Ling, N. and Jackson, I.M.D., 1986. Purification and characterization of luteinizing hormone-releasing hormone from codfish brain. Regulatory Peptides, 15: 311-321. 